\title{
Pollutant Removal in Stormwater by Woodchips
}

\author{
Michelle A M Hopkins ${ }^{1}$, Adella M Kuster ${ }^{2}$, Jason R Vogel ${ }^{1,2 *}$ and Glenn 0 Brown ${ }^{1}$ \\ ${ }^{1}$ Department of Biosystems and Agricultural Engineering, Oklahoma State University, Stillwater, OK, USA \\ ${ }^{2}$ Department of Civil Engineering and Environmental Science, University of Oklahoma, Norman, OK, USA
}

Submission: December 22, 2020; Published: January 19, 2021

*Corresponding author: Jason R Vogel, Department of Biosystems and Agricultural Engineering, Oklahoma State University, Stillwater, OK \& Department of Civil Engineering and Environmental Science, University of Oklahoma, Norman, OK, USA

Abstract

As urbanization continues, water pollution is of increasing concern for human health and the environment. Water contaminants common in urban stormwater include nutrients, metals, suspended solids, pesticides, and pathogens. The search for an inexpensive and readily available material that can effectively remove common stormwater contaminants is ongoing. Studies have shown that woodchips are a promising material that can remove many different contaminants, including these common contaminants and emerging contaminants of concern. The type of wood and shape of woodchips can impact the removal efficiencies of different contaminants due to different partitioning coefficients and capillary action. This review compiles studies on the ability of woodchips of different types to remove these common stormwater contaminants and emerging contaminants of concern. Overall, the literature demonstrated woodchips are an inexpensive and effective material that could be implemented for the removal of contaminants in urban stormwater.

Keywords: Water contaminants; Woodchips; Biological degradation; Pollutants; Aquatic organisms; Environment

\section{Introduction}

In an ever-urbanizing society, water pollution is becoming more of a concern for human health and the health of the environment. There are many water contaminants associated with urbanization including nutrients, heavy metals, eroded sediment, hydrocarbons, and pathogens. As water pollution continues to increase, the search for inexpensive, readily available, and effective treatment techniques for remediating pollution in runoff is increasingly important. Woodchips have been investigated as an inexpensive treatment medium for many types of pollutants. Woodchips remove these pollutants by utilizing processes such as filtration, sorption, and biological degradation, and performance can be influenced by wood properties such as type of wood and shape. This review summarizes a variety of studies that demonstrate the use of woodchips for effectively removing a variety of pollutants. Utilizing this readily available material for pollutant removal from stormwater runoff could provide a low-cost, sustainable solution for water-quality improvement in stormwater runoff across the globe.

\section{Pollutant Removal}

Common stormwater contaminants vary in chemical properties, resulting in different impacts on human health and the environment and different removal processes. Sorption is one process woodchips utilize to remove pollutants. Woodchips are a porous material, so they contain small capillaries where water can flow by capillary action [1]. As the water flows through the capillaries, pollutants sorb to the woodchips and are removed from the water. Woodchips also remove some pollutants through physical processes, such as filtration, where woodchips intercept the flow of water, allowing suspended contaminants to stick to the woodchips and in the pores of the woodchips, removing them from the water [2]. Retention of pathogens in the woodchips can expedite deactivation of pathogens through natural decay, desiccation, or predation [3]. Ion exchange can also occur when cations replace phenolic hydroxyl groups, found in the tannins in woodchips [4]. Another process woodchips utilize to remove pollutants is biological degradation, which can occur in toxic or anoxic conditions. Most organic matter is degraded through oxidation by aerobic bacteria. The oxygen that is required for degradation of the organic material present in the water is represented by BOD or COD, so as organic matter is degraded, BOD and COD will decrease. Denitrification occurs in anoxic zones with low ventilation efficiency, such as the pores of woodchips or saturated zones [5]. Denitrifying bacteria use woodchips as a carbon source and nitrates as a terminal electron acceptor, 
resulting in the conversion of nitrates to nitrogen gas [5].

\section{Water quality indicators}

Water quality indicators include biological oxygen demand (BOD), chemical oxygen demand (COD), and suspended solids and are indicative of poor water quality that may be caused by pollutants such as excess nutrients, oils and grease, and/or sediment. BOD and COD are indicative of organic material in the water, and suspended solids can have other pollutants adsorbed to them, so their removal is imperative. BOD and COD are removed by biological degradation, and suspended solids are removed through physical filtration by woodchips [6-10].

\section{Nutrients}

Excess nutrients in water can cause issues, such as eutrophication. Many studies have found that woodchips remove nutrients from water, including nitrate, sulphate, ammonia, ammonium, nitrite, orthophorphorus, and particulate phosphorus $[2,3,5,6,9,11-17]$. Nutrients vary in their chemical properties, so their removal processes vary as well. Woodchips act as the carbon source in the biological degradation of nitrate, sulphate, ammonia, ammonium, and nitrite $[5,13]$. Particulate phosphorus is phosphorus adsorbed to suspended sediment, so it is removed by physical filtration along with suspended solids [2]. Orthophosphorus, is removed through sorption, and nitrates can be removed by sorption as well as biological degradation [14].

\section{Heavy metals}

Heavy metals can be toxic to humans and aquatic organisms, and their presence can disrupt aquatic ecosystems. Mulch and woodchips have proven effective for heavy metal removal, but some metals, such as arsenic, have not been studied [4,13,18-21]. Metals are removed through sorption to the woodchips and cation exchange with phenolic hydroxyl groups. The composition of the wood can greatly affect the removal efficiency of the metals [4].

\section{Pesticides}

Pesticides often persist long term in the environment and are detrimental to human health and the environment. Many pesticides are organochlorides, which interact with the organic material in the woodchips through sorption [22] or physical filtration of sediment on which pesticides are sorbed [23]. Several studies have found woodchips to effectively remove pesticides $[15,21,22,24,25]$.

\section{Total petroleum hydrocarbons}

Total petroleum hydrocarbons describe a broad family of chemical compounds associated with crude oil, including aliphatic hydrocarbons, polycyclic aromatic hydrocarbons (PAHs), and monocyclic aromatic hydrocarbons (MAHs) (ASTDR, 1999). They have shown to be effectively removed by wood products in many studies, by sorption to the woodchips as well as physical filtration of sediments to which hydrocarbons are sorbed and biological degradation [19,24,26-29].

\section{Other halocarbons}

Other halocarbons have similar characteristics to pesticides and have also been found to be removed by wood through sorption. The other halocarbons studies include surfactants [28], fluorene [27], 1,3-Dichlorobenzene, butylbenzylphthalate, fluoranthene [19], trichloroethene [30], 1,2-Dichlorobenzene, 1,3,5-Trichlorobenzene, and chlorobenzene [24].

\section{Pathogens}

Pathogens present a risk to the health of humans and aquatic organisms and are often indicative of fecal material in water. There is a limited amount of research evaluating the ability of wood to remove water-borne pathogens. Soupir et al. [3] evaluated the removal of E. coli and Salmonella, and Rambags et al. [31] evaluated the removal of $E$. coli and F-specific RNA bacteriophage, an indicator of viral pollution, by wood products, both finding effective removal of these pathogens. Pathogens are removed by sorption to woodchips or physical filtration if they are adsorbed to sediments in the inflow, causing the deactivation of pathogens by natural decay, desiccation, or predation [3].

\section{Other emerging contaminants}

Other pollutants that wood mulch can treat include explosives such as Trinitrotoluene (TNT), Rapid Detonating Explosive (RDX), and octogen (HMX) [32]; and emerging contaminants [33]. The chemical structures and properties and environmental impact of these contaminants vary greatly, but they all have potential of being removed by wood products. Less is known about the interactions of these chemicals with woodchips, but many emerging contaminants are likely removed by sorption (Table 1).

\section{Effect of Woodchip Shape and Type}

Woodchips are broadly effective for the removal of common stormwater contaminants, but their effectiveness can be impacted by both shape and type. The shape of the woodchips affects the way water flows through the pore spaces in the woodchips, which can affect sorption, ion exchange capacity, and even biological degradation. Additionally, different types of wood have different chemical compositions, which can lead to different sorption and ion exchange abilities.

\section{Shape of woodchips}

Wood's sorption and ion exchange capacity are impacted by capillary flow, which is the movement of liquid by capillary action. Washburn [34] defined capillary action for straight cylindrical tubing as,

$$
l^{2}=\frac{\gamma D \cos (\theta)}{4 \eta} t=K t
$$

where $l$ is the length the fluid traveled, $\gamma$ is the surface tension, $D$ is the tube diameter, $t$ is time, $\theta$ is the contact angle, $\eta$ is the dynamic viscosity, and $K$ is referred to as the Washburn slope. The 
Washburn equation, that assumes straight capillary tubes, can be adapted for use in porous media that have tortuous connecting pores. In fibrous materials, such as woodchips, the pore spaces are irregular. This can cause variations in the effective pore diameter and contact angle. Wålinder \& Gardner [35] examine the factors influencing effective pore radius and contact angle in spruce chips with several different wetting fluids. They used fluids that have low surface tensions, methanol and hexane, with an effective contact angle of zero. From those experiments, the effective pore diameter for the spruce chips was found [36].

Table 1: Literature summary of pollutant removal from water by wood mulch. TPH $=$ Total Petroleum Hydrocarbons, PAH $=$ Polycyclic Aromatic Hydrocarbon, $\mathrm{MAH}=$ Monocyclic Aromatic Hydrocarbon, $\mathrm{Cd}=$ Cadmium, $\mathrm{Cr}=$ chromium, $\mathrm{Hg}=$ Mercury, $\mathrm{Pb}=$ lead, $\mathrm{Mn}=\mathrm{Manganese}, \mathrm{Cu}=\mathrm{Cop}-$ per, $\mathrm{Zn}=$ Zinc, $\mathrm{WQ}=$ Water Quality, BOD = Biochemical Oxygen Demand, COD = Chemical Oxygen Demand, SS = Suspended Solids and TSS $=$ Total Suspended Solids.

\begin{tabular}{|c|c|c|c|c|}
\hline & Target Pollutant & Wood Type(s) & Research Focus & Reference \\
\hline \multirow{5}{*}{ 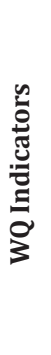 } & COD, TSS & Woodchip and pumice & Constructed wetland & Niu et al. [10] \\
\hline & BOD, COD, SS & Multiple types (review paper) & Greywater treatment & Dalahmeh et al. [8] \\
\hline & BOD & Eucalypt wood mulch & Constructed wetland & Saeed and Sun [9] \\
\hline & BOD & Wood mulch & Biofiltration for compost liquor & Savage and Tyrrl [6] \\
\hline & BOD, COD, TSS & Wood mulch & Greywater treatment & Zuma et al. [7] \\
\hline \multirow{12}{*}{$\sum_{z}^{\stackrel{0}{0}}$} & Nitrate & Hardwood chips & $\begin{array}{l}\text { Effect of temperature and reten- } \\
\text { tion time }\end{array}$ & Soupir et al. [3] \\
\hline & Nitrate, nitrite ammonia & Pine woodchips & Mine water treatment & $\begin{array}{l}\text { Nordström and Herbert } \\
\text { [17] }\end{array}$ \\
\hline & Particulate phosphorus & Monterey pine woodchips & $\begin{array}{l}\text { Woodchip filtration of agricultural } \\
\text { runoff }\end{array}$ & Choudhury et al. [2] \\
\hline & $\begin{array}{c}\text { Ammonia, nitrate, nitrite, ortho- } \\
\text { phosphorus }\end{array}$ & Wood chips and fibers & Septic tank leachate & Xuan et al. [14] \\
\hline & Ammonia, Ammonium & Wood mulch & Biofiltration for compost liquor & Savage and Tyrrl [6] \\
\hline & \multirow{5}{*}{ Nitrate } & Pine wood mulch and wheat straw & Bioreactors & Camilo et al [15] \\
\hline & & Pine bark mulch & Landfill leachate & Frank et al [16] \\
\hline & & $\begin{array}{l}\text { Softwood branches and bark, } \\
\text { hardwood chips and branches, co- } \\
\text { niferous twigs and leaves, mulch, } \\
\text { willow wood chips, compost, and } \\
\text { beech leaves }\end{array}$ & $\begin{array}{l}\text { Permeable Reactive Barrier for } \\
\text { groundwater }\end{array}$ & Gibert et al. [12] \\
\hline & & Wood chips & Bioretention for urban runoff & Kim et al [5] \\
\hline & & $\begin{array}{l}\text { Wood mulch, sawdust, leaf } \\
\text { compost }\end{array}$ & $\begin{array}{l}\text { Permeable Reactive Barrier for } \\
\text { groundwater }\end{array}$ & Robertson et al [11] \\
\hline & \multirow{2}{*}{ Sulphate } & Eucalypt wood mulch & Constructed wetland & Saeed and Sun [9] \\
\hline & & Chipped wood mulch & Bioreactor for mine drainage & Edwards et al [13] \\
\hline \multirow{6}{*}{ 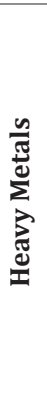 } & $\mathrm{Cd}, \mathrm{Cu}, \mathrm{Ni}, \mathrm{Pb}, \mathrm{Zn}$ & $\begin{array}{l}\text { California redwood, oak, Douglas } \\
\text { fir woodchips }\end{array}$ & $\begin{array}{l}\text { Effect of biochar and straw } \\
\text { additives }\end{array}$ & Ashoori et al [21] \\
\hline & $\mathrm{Cd}, \mathrm{Cr}(\mathrm{III}), \mathrm{Cr}(\mathrm{VI}), \mathrm{Hg}, \mathrm{Pb}$ & Multiple (review paper) & $\begin{array}{l}\text { Potentially low-cost sorbents for } \\
\text { heavy metals }\end{array}$ & Bailey et al [4] \\
\hline & $\mathrm{Mn}$ & Chipped wood mulch & Bioreactor for mine drainage & Edwards et al [13] \\
\hline & $\mathrm{Cu}, \mathrm{Pb}, \mathrm{Zn}$ & $\begin{array}{l}\text { Cypress bark, hardwood bark, } \\
\text { pine bark nugget }\end{array}$ & Urban runoff & Jang et al [18] \\
\hline & $\mathrm{Cu}, \mathrm{Cd}, \mathrm{Cr}, \mathrm{Pb}, \mathrm{Zn}$ & Hardwood mulch & Heavy metal and organic removal & Ray et al. [19] \\
\hline & $\mathrm{Cu}, \mathrm{Zn}, \mathrm{Pb}$ & Packing wood & Urban runoff & Seelsaen et al. [20] \\
\hline
\end{tabular}




\section{International Journal of Environmental Sciences \& Natural Resources}

\begin{tabular}{|c|c|c|c|c|}
\hline \multirow{5}{*}{ 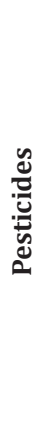 } & Fipronil, diuron, atrazine, 2,4-D & $\begin{array}{l}\text { California redwood, oak, Douglas } \\
\text { fir woodchips }\end{array}$ & $\begin{array}{l}\text { Effect of biochar and straw } \\
\text { additives }\end{array}$ & Ashoori et al. [21] \\
\hline & $\begin{array}{l}\text { Heptachlor, aldrin, endrin, diel- } \\
\text { drin, DDD, DDT, DDE }\end{array}$ & Pine bark & Halocarbon pesticide removal & Bras et al. [22] \\
\hline & Atrazine, bentazone & Pine wood mulch and wheat straw & Bioreactors & Camilo et al. [15] \\
\hline & $\begin{array}{l}\text { Diuron, isoxaben, oryzalin, clopy- } \\
\text { ralid }\end{array}$ & Shredded cedar mulch & Herbicide removal & Huang et al. [25] \\
\hline & DDT & Willow branches, oak branches & Wood Sorption Capacity & Trapp et al. [24] \\
\hline \multirow{5}{*}{$i_{0}^{T}$} & $\begin{array}{l}\text { PAH (anthracene), MAH (naphtha- } \\
\text { lene and pyrene) }\end{array}$ & Aspen wood fibers & Wood sorption capacity & Boving \& Zhang [27] \\
\hline & $\begin{array}{l}\text { MAH (benzene, toluene, and } \\
\text { o-xylene) }\end{array}$ & Douglas fir and Ponderosa pine & Wood sorption capacity & MacKay \& Gschwend [26] \\
\hline & $\begin{array}{l}\text { MAH (naphthalene and benzopy- } \\
\text { rene) }\end{array}$ & $\begin{array}{c}\text { Hardwood mulch (combination of } \\
\text { Silver Maple, Norway Maple, Red } \\
\text { Oak, and Cherry) }\end{array}$ & Heavy metal and organics removal & Ray et al. [19] \\
\hline & PAH (phenanthrene and pyrene) & Hardwood bark mulch & Biofilm barrier for groundwater & Seo et al. [28] \\
\hline & $\begin{array}{l}\text { MAH (benzene, phenol, xylene, } \\
\text { and naphthalene) }\end{array}$ & Willow branches, oak branches & Wood sorption capacity & Trapp et al. [24] \\
\hline \multirow{5}{*}{ 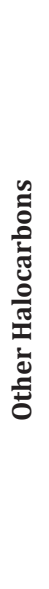 } & Fluorene & Aspen wood fibers & Wood Sorption Capacity & Boving and Zhang [27] \\
\hline & $\begin{array}{l}\text { 1,3-Dichlorobenzene, butylbenzyl- } \\
\text { phthalate, and fluoranthene }\end{array}$ & $\begin{array}{c}\text { Hardwood mulch (combination of } \\
\text { Silver Maple, Norway Maple, Red } \\
\text { Oak, and Cherry) }\end{array}$ & Heavy metal and organic removal & Ray et al. [19] \\
\hline & Surfactant & Hardwood bark mulch & Biofilm Barrier for groundwater & Seo et al. [28] \\
\hline & Trichloroethylene & $\begin{array}{l}\text { Shredded tree mulch and cotton } \\
\text { gin trash }\end{array}$ & $\begin{array}{l}\text { Permeable Reactive Barrier for } \\
\text { groundwater }\end{array}$ & Shenl et al. [30] \\
\hline & $\begin{array}{l}\text { 1,2-Dichlorobenzene, 1,3,5-Tri- } \\
\text { chlorobenzene, and chlorobenzene }\end{array}$ & Willow branches, oak branches & $\begin{array}{l}\text { Sorption of lipophilic organic } \\
\text { compounds }\end{array}$ & Trapp et al. [24] \\
\hline \multirow{2}{*}{ 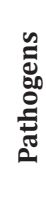 } & E. coli, Salmonella & Hardwood chips & $\begin{array}{l}\text { Effect of temperature and reten- } \\
\text { tion time }\end{array}$ & Soupir et al. [3] \\
\hline & $\begin{array}{l}\text { E. coli, F-specific RNA bacterio- } \\
\text { phage }\end{array}$ & Monterey pine woodchips & Denitrifying woodchip bioreactor & Rambags et al. [31] \\
\hline \multirow{2}{*}{ 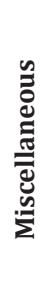 } & $\begin{array}{c}\text { Acetaminophen, caffeine, carba- } \\
\text { mazepine, ibuprofen, sulfathiazole, } \\
\text { benzotriazole, } 5 \text {-methyl-1H-ben- } \\
\text { zotriazole }\end{array}$ & $\begin{array}{l}\text { California redwood, oak, Douglas } \\
\text { fir woodchips }\end{array}$ & Emerging contaminant removal & Tseng et al. [33] \\
\hline & TNT, RDX, HMX & Pine bark, pine mulch & $\begin{array}{l}\text { Permeable reactive barrier for } \\
\text { groundwater }\end{array}$ & Ahmad et al. [32] \\
\hline
\end{tabular}


Staples \& Shaffer [1] present an equation that was catered to capillary rise in porous media rather than using the Washburn equation that was intended for straight cylindrical tubing. This was done by testing the wetting front of saline in uniform glass bead beds to find the simplistic flow front model,

$$
\ln \left(l-\frac{l}{l_{e q}}\right)+\frac{l}{l_{e q}}=\frac{D_{v i s}^{2} \rho g}{32 \eta l_{e q}} t
$$

where $D_{\text {vis }}$ is the diameter at the throat that limits viscous drag, $\rho$ is the fluid density, $g$ is the gravity constant, $t$ is the time, and $l_{e q}$ is the equilibrium length, which is a function of surface tension, contact angle, throat diameter, density, and gravity given by,

$$
l_{e q}=\frac{4 \gamma \cos \theta}{D_{c a p} \rho g}
$$

where $D_{\text {cap }}$ is the diameter at the largest portion of the tube that limits capillary pressure. More research is needed to determine what shape and size of woodchips would have the highest removal efficiencies.

\section{Type of wood}

Trees can be categorized as either softwoods or hardwoods. Softwoods are coniferous trees that produce their seeds in cones. Examples of softwoods are cedar, redwoods, and pine. Hardwoods are flowering trees that produce their seeds in fruit. Some hardwoods are denser than others and are further separated as soft hardwoods and hard hardwoods. Examples of soft hardwoods include cottonwoods, balsa, and willows. Examples of hard hardwoods include oak, hickory, and mahogany. Softwoods generally have higher amounts of lignin than hardwoods. Lignin contains polyhydric phenols and other functional groups on its surface, making it important in the role of woodchips as a sorbent for metals and hydrocarbons [4]. Bailey et al.[4] found that sorption of metals, such as copper, chromium, zinc, nickel, mercury, and lead on woodchips occurred primarily on the lignin or tannin components (1999). MacKay \& Gschwend [26] found that two different softwoods, Douglas fir and Ponderosa pine, had a high equilibrium sorption capacity for benzene, o-xylene, and toluene. They also combined the work of Stamm \& Millet [37], Garbarini \& Lion [38], Xing et al. [39] and Severtson \& Banerjee [40] to determine a relationship between the ligninwater partition coefficient of the wood $\left(K_{\text {lignin }}\right)$ and octanol-water partition coefficient of the chemical $\left(K_{o w}\right)$. The additional chemicals include other petroleum hydrocarbons and chlorocarbons such as phenol, trichloroethylene, dichlorophenol, and trichlorophenol. The best fit regression for $K_{\text {lignin }}$ and $K_{o w}$ of the data that MacKay \& Gschwend [26] compiled is,

$$
\log K_{\text {lingin }}=0.74( \pm 0.09) \log K_{o w}-0.04( \pm 0.25)
$$
$\mathrm{mL} \cdot \mathrm{g}^{-1}$.

where $K_{\text {lignin }}$ is in $\left(\mathrm{mol} \cdot \mathrm{g}_{\text {lignin }}{ }^{-1}\right) \cdot\left(\mathrm{mol} \cdot \mathrm{mL}_{\text {water }}{ }^{-1}\right)^{-1}$ and $K_{\text {ow }}$ is in

Lignin has been found to have a high sorption capacity for hydrocarbons and metals, which makes woods with high lignin content more efficient sorbents.

\section{Conclusion}

These studies have shown that woodchips are an effective material for the removal of many different contaminants from water. There are still some unanswered questions in the literature regarding the pollutant removal capabilities of woodchips, including:

a) What is the effect of moisture content on the ability of woodchips to remove contaminants?

b) What is the effect of external factors, such as humidity, solar radiation, and wind speed on the ability of woodchips to remove contaminants?

c) How well can woodchips remove other pollutants, such as arsenic, that have not been previously investigated?

d) What shape and size of woodchips are most effective for pollutant removal?

The literature has shown that woodchips can effectively remove many different contaminants of concern that are commonly found in urban runoff. It is a promising and inexpensive material that could be widely implemented to reduce the transport of contaminants through stormwater.

\section{References}

1. Staples TL, Shaffer DG (2002) Wicking flow in irregular capillaries. Colloids and Surfaces a-Physicochemical and Engineering Aspects 204(1-3): 239-250.

2. Choudhury T, Robertson WD, Finnigan DS (2016) Suspended Sediment and Phosphorus Removal in a Woodchip Filter System Treating Agricultural Wash Water. Journal of Environmental Quality 45(3): 796802.

3. Soupir M, Hoover N, Moorman T, Law J, Bearson B (2018) Impact of temperature and hydraulic retention time on pathogen and nutrient removal in woodchip bioreactors. Ecological Engineering 112: 153157.

4. Bailey SE, Olin TJ, Bricka RM, Adrian DD (1999) A review of potentially low-cost sorbents for heavy metals. Water Research 33(11): 24692479.

5. Kim HH, Seagren EA, Davis AP (2003) Engineered bioretention for removal of nitrate from stormwater runoff. Water Environment Research 75(4): 355-367.

6. Savage AJ, Tyrrel SF (2005) Compost liquor bioremediation using waste materials as biofiltration media. Bioresource Technology 96(5): 557-564.

7. Zuma BM, Tandlich R, Whittington Jones KJ, Burgess JE (2008) Mulch tower treatment system Part I: Overall performance in greywater treatment. Desalination 242(1-3): 38-45.

8. Dalahmeh SS, Hylander LD, Vinneras B, Pell M, Oborn I, et al. (2011) Potential of organic filter materials for treating greywater to achieve irrigation quality: a review. Water Science and Technology 63(9): 1832-1840.

9. Saeed T, Sun GZ (2011) Enhanced denitrification and organics removal in hybrid wetland columns: Comparative experiments. Bioresource Technology 102(2): 967-974. 
10. Niu S, Wang X, Yu J, Kim Y (2018) Pollution reduction by recirculated fill-and-drain mesocosm wetlands packed with woodchip/pumice treating impervious road stormwater. Environmental Technology 41(13): 1627-1636.

11. Robertson WD, Blowes DW, Ptacek CJ, Cherry JA (2000) Long-term performance of in situ reactive barriers for nitrate remediation. Ground Water 38(5): 689-695

12. Gibert O, Pomierny S, Rowe I, Kalin RM (2008) Selection of organic substrates as potential reactive materials for use in a denitrification permeable reactive barrier (PRB). Bioresource Technology 99(16): 7587-7596.

13. Edwards JD, Barton CD, Karathanasis AD (2009) A Small-Scale SulfateReducing Bioreactor for Manganese Removal from a Synthetic Mine Drainage. Water Air and Soil Pollution 203(1-4): 267-275.

14. Xuan ZM, Chang NB, Wanielista M, Hossain F (2010) Laboratory-Scale Characterization of a Green Sorption Medium for On-Site Sewage Treatment and Disposal to Improve Nutrient Removal. Environmental Engineering Science 27(4): 301-312.

15. Camilo BK, Matzinger A, Litz N, Tedesco LP, Wessolek G (2013) Concurrent nitrate and atrazine retention in bioreactors of straw and bark mulch at short hydraulic residence times. Ecological Engineering 55: 101-113.

16. Frank R, Trois C, Coulon F (2015) Sustainable landfill leachate treatment using refuse and pine bark as a carbon source for biodenitrification. Environmental Technology 36(11): 1347-1358.

17. Nordström A, Herbert RB (2017) Identification of the temporal control on nitrate removal rate variability in a denitrifying woodchip bioreactor. Mine Water and Circular Economy, pp. 1087-1094.

18. Jang A, Seo Y, Bishop PL (2005) The removal of heavy metals in urban runoff by sorption on mulch. Environmental Pollution 133(1): 117 127.

19. Ray AB, Selvakumar A, Tafuri AN (2006) Removal of selected pollutants from aqueous media by hardwood mulch. Journal of Hazardous Materials 136(2): 213-218.

20. Seelsaen N, McLaughlan R, Moore S, Stuetz RM (2006) Pollutant removal efficiency of alternative filtration media in stormwater treatment. Water Science and Technology 54(6-7): 299-305.

21. Ashoori N, Teixido M, Spahr S, Lefevre GH, Sedlak DL, et al. (2019) Evaluation of pilot-scale biochar-amended woodchip bioreactors to remove nitrate, metals, and trace organic contaminants from urban stormwater runoff. Water Research 154: 1-11.

22. Bras IP, Santos L, Alves A (1999) Organochlorine pesticides removal by pinus bark sorption. Environmental Science \& Technology 33(4): 631-634.

23. McMaine JT, Vogel JR, Belden JB, Schnelle MA, Morrison SA, et al. (2019) Field studies of pollutant removal from nursery and greenhouse runoff by constructed wetlands. Journal of Environmental Quality 49(1): 106118.

24. Trapp S, Miglioranza KSB, Mosbaek H (2001) Sorption of lipophilic organic compounds to wood and implications for their environmental fate. Environmental Science \& Technology 35(8): 1561-1566.
25. Huang XJ, Massoudieh A, Young TM (2006) Measured and predicted herbicide removal by mulch. Journal of Environmental EngineeringAsce 132(8): 918-925.

26. Mackay AA, Gschwend PM (2000) Sorption of monoaromatic hydrocarbons to wood. Environmental Science \& Technology 34(5): 839-845.

27. Boving TB, Zhang W (2004) Removal of aqueous-phase polynuclear aromatic hydrocarbons using aspen wood fibers. Chemosphere 54(7): 831-839.

28. Seo Y, Lee WH, Sorial G, Bishop PL (2009) The application of a mulch biofilm barrier for surfactant enhanced polycyclic aromatic hydrocarbon bioremediation. Environmental Pollution 157(1): 95101.

29. Melone MA (2016) Bio-separator Design Improvements for Removal of Petroleum Hydrocarbons from Runoff (Master's thesis, Oklahoma State University, Stillwater, Oklahoma, USA).

30. Shenl H, Adair C, Wilson JT (2010) Long-Term Capacity of Plant Mulch to Remediate Trichloroethylene in Groundwater. Journal of Environmental Engineering-Asce 136(10): 1054-1062.

31. Rambags F, Tanner CC, Stott R, Schipper LA (2016) Fecal Bacteria Bacteriophage, and Nutrient Reductions in a Full-Scale Denitrifying Woodchip Bioreactor. Journal of Environmental Quality 45(3): 847854 .

32. Ahmad F, Schnitker SP, Newell CJ (2007) Remediation of RDX- and HMX-contaminated groundwater using organic mulch permeable reactive barriers. Journal of Contaminant Hydrology 90(1-2): 1-20.

33. Tseng Y, Lai WW, Tung H, Lin AY (2020) Pharmaceutical and anticorrosive substance removal by woodchip column reactor: Removal process and effects of operational parameters. Environmental Science: Processes \& Impacts 22(1): 187-196.

34. Washburn EW (1921) The dynamics of capillary flow. Physical Review 17(3): 273-283.

35. Wålinder MEP, Gardner DJ (1999) Factors influencing contact angle measurements on wood particles by column wicking. Journal of Adhesion Science and Technology 13(12): 1363-1374.

36. Van Oss CJ, Giese RF, Li Z, Murphy K, Norris J, et al. (1992) Determination of contact angles and pore sizes of porous-media by column and thinlayer wicking. Journal of Adhesion Science and Technology 6(4): 413428.

37. Stamm AJ, Millett MA (1941) The internal surface of cellulosic materials. Journal of Physical Chemistry 45(1): 43-54.

38. Garbarini DR, Lion LW (1986) Influence of the nature of soil organics on the sorption of toluene and trichloroethylene. Environmental Science \& Technology 20(12): 1263-1269.

39. Xing BS, McGill WB, Dudas MJ (1994) Cross-correlation of polarity curves to predict partition-coefficients of nonionic organic contaminants. Environmental Science \& Technology 28(11): 19291933.

40. Severtson SJ, Banerjee S (1996) Sorption of chlorophenols to wood pulp. Environmental Science \& Technology 30(6): 1961-1969. 
(C) Commons Attribution 4.0 License

(CC) DOI:10.19080/IJESNR.2021.26.556200
Your next submission with Juniper Publishers will reach you the below assets

- Quality Editorial service

- Swift Peer Review

- Reprints availability

- E-prints Service

- Manuscript Podcast for convenient understanding

- Global attainment for your research

- Manuscript accessibility in different formats ( Pdf, E-pub, Full Text, Audio)

- Unceasing customer service

Track the below URL for one-step submission https://juniperpublishers.com/online-submission.php 